\title{
Heavy metals accumulation in Nerium oleander leaves across urban areas in Setif region, Algeria
}

\author{
MOHAMED AMINE KOUCIM, AMINA BELGUIDOUM, TAKIA LOGRADA, MESSAOUD RAMDANI \\ Laboratory for Valorization of Natural Biological Resources, SNV Faculty, Ferhat Abbas University. Setif-1. El Bez, Setif 19000, Algeria. \\ Tel.: +213-658-101010, `email: ramdanimessaoud@yahoo.com
}

Manuscript received: 13 April 2021. Revision accepted: 8 May 2021.

\begin{abstract}
Koucim MA, Belguidoum A, Lograda T, Ramdani M. 2021. Heavy metals accumulation in Nerium oleander leaves across urban areas in Setif region, Algeria. Biodiversitas 22: 3083-3091. Pollution by Metallic trace elements (MTE) has become one of the most serious environmental problems resulting from human activity. Plants, which are the base of the food chain, can take up MTE from the soil solution; hyper-accumulators can store high levels of heavy metals in their aerial parts at high concentrations. These plants can be used in phytoremediation. This study aimed to investigate the accumulation of MTE in the leaves of Nerium oleander to monitor environmental pollution of several areas in the province of Setif, Algeria. The samples of $N$. oleander leaves were collected from 20 urban areas in Setif Province. The concentrations of seven metallic trace elements $(\mathrm{Cd}, \mathrm{Mn}, \mathrm{Pb}, \mathrm{Sb}, \mathrm{Cu}, \mathrm{Bi}$ and $\mathrm{Fe})$ were determined using Flame Atomic Absorption Spectrophotometry (AASF). The results show that the concentrations of heavy metals in the leaves of $N$. oleander, in general, were very high, far exceeding the certified standard ranges. The order of MTE in the leaves was found as follows: $\mathrm{Mn}>\mathrm{Sb}>\mathrm{Bi}>\mathrm{Pb}>\mathrm{Fe}>\mathrm{Cu}>\mathrm{Cd}$. Our findings indicate that although $N$. oleander showed a significant capacity to accumulate MTE, the urban areas of Setif province were highly polluted by heavy metals. The presence of metal ions in the aerial parts of the plant indicates that $N$. oleander is a hyper-accumulator of metals with tolerance to $\mathrm{Mn}, \mathrm{Sb}$, and $\mathrm{Pb}$, and can be used as a bio-monitor. This opens up prospects for its application for soil phytoremediation.
\end{abstract}

Keywords: phytoremediation, bio-indicator, bio-accumulation, Nerium oleander, heavy metals, pollution, Algeria

\section{INTRODUCTION}

The environmental pollution by heavy metals and their accumulation have increased dramatically in the past decades, raising significant concerns worldwide (Suman et al. 2018; Ashraf et al. 2019). Heavy metals are not biodegradable and are prone to accumulate in living organisms as metallic trace elements (MTE) (Tchounwou et al. 2012). MTE are a group of metallic chemical elements from natural or anthropogenic sources (Farahat and Linderholm 2015; Chen et al. 2016; Hodomihou et al. 2016; Iqbal et al. 2016; Pichtel 2016). Many metallic elements are known for their toxicities (Nordberg et al. 2015). While some metals such as zinc, iron and copper are essential for plants and animals, they can be very toxic to humans (Tchounwou et al. 2012).

The mitigation of MTE toxification risks in humans requires environmental monitoring to help developing appropriate treatments, for example establishing safe disposal of pollutants (Schreck et al. 2012). The implementation of quality monitoring of the contaminated environment is imperative to reduce pollutant levels, particularly in urban areas where metallic pollutants often act together, making it difficult to reveal their effects (Lodenius et al. 2010; Pandey et al. 2014; GonzalezCastanedo et al. 2014; Parzych et al. 2016; Chen et al. 2016; Hankey et Marshall 2017; Fioravanti et al. 2018). One method of MTE monitoring in contaminated soils uses chemical and physical technologies, however, this approach is neither environmentally friendly nor costeffective, especially in large and unproductive urban areas; in addition, it requires huge financial and labor investments (Venkateswarlu et al. 2016; Napoli et al. 2019).

Another monitoring method of MTE pollution is the use of bio accumulators, such as plants, in a diagnostic study. This method is very advantageous since the cost is low and it can be used on a large scale with high efficiency, offering an interesting tool to monitor heavy metal contamination in the air and soils (Pirintsos and Loppi 2008; Stamenkovic et al. 2013; Antonucci et al. 2016; Belguidoum et al. 2020). Several higher plants have been used to assess metal contamination in the air and soils because of their accumulation properties (Al-Khlaifat and Al-Khashman 2007; Berlizov et al. 2007; Di Lonardo et al. 2011; Youssef et al. 2014, Belguidoum et al. 2020; Vannucchi et al. 2020). Studies have shown that the leaves of higher plants adsorb MTE from wet and dry atmospheric deposition and accumulate metals from the soil and the atmosphere (Maher et al. 2008; Barış et al. 2015; Lograda et al. 2016).

Plant leaves are widely used as a bioindicator due to their ability to absorb air pollutants through the stomata, cuticle or indirectly through uptake through the roots after deposition of air pollutants from the soil (Ernst 2003). Urban trees can remove some of the particles from the air because they have a large leaf area, capturing pollutants on the foliage (Tallis et al. 2011; Speak et al. 2012). Besides the role of plants as bio-monitoring agents of polluted environment, a study by Sivakumar et al. (2020) showed 
that several plants are also very effective for phytoremediation of heavy metals, suggesting that they could be used to decontaminate soil polluted by heavy metals.

Nerium oleander is a xerophytic and perennial evergreen species of the Apocynaceae family. It can survive in soils polluted by heavy metals due to its strong exclusionary behavior (Franco et al. 2012, 2013). Showing a good capacity for bioaccumulation of $\mathrm{Pb}, \mathrm{Cu}, \mathrm{Cd}, \mathrm{Sb}$, and Mn (Aksoy and Ozturk 1997; Espinosa and Oliva 2006; Mingorance and Oliva 2006; Mingorance et al. 2007; Santos et al. 2019; Ibrahim and El Afandi 2020a and b), it is used as a biomonitor of heavy metals in Mediterranean areas. In Algeria, this species is widely distributed in urban areas.

The main target of this study is to determine heavy metal concentrations in leaves of Nerium oleander planted in the roads of twenty stations in the province of Setif (Algeria) in order to evaluate its ability to remove pollutants from, and thus to be used for monitoring environment quality.

\section{MATERIALS AND METHODS}

\section{Study area}

Twenty observation stations located in the province of Sétif, Algeria, were selected to sample Nerium oleander (Figure 1; Table 1). The samples were collected in urban areas of the Sétif region, Algeria, during March 2020. The climate of the study area is semi-arid, cold in winter, and hot in summer. The average annual rainfall is $322 \mathrm{~mm}$ and rarely exceeds $500 \mathrm{~mm}$ and the annual average temperature is $15^{\circ} \mathrm{C}$ (Gharzouli 2007).
The sources of pollution in the Setif region are mainly from industry, agriculture, a road network which is composed of several types (the East-West Highway, the national roads (RN) (NR5, RN9, RN28, RN75, RN78,), a set of secondary roads and more or less developed tracks), two railway lines and airport.

\section{Selection of the plant}

Nerium oleander is a species with very original leaves, persistent, gray, and thick, forming a dense ground cover. It flowers in spring with bright yellow color. This species is native to Algeria and popular in the urban area. The selection of $N$. oleander is based on a previous study on the bioaccumulation of heavy metals in this species (Santos et al. 2019; Belguidoum et al. 2020; Ibrahim and El Afandi $2020 \mathrm{a}$ and $\mathrm{b}$ ). The selected plant is a common and typical shrub and is planted for landscape purposes in Setif. It grows in almost all urban parks and streets, even where urban pollution levels are high. This plant is found in large numbers in the monitoring areas and can be easily identified. Sampling was done randomly, depending on the abundance of the plant species at the site level. The samples were transported to the laboratory in paper bags.

\section{Sample's preparation \\ Cleaning and grinding}

These activities consisted of eliminating any atmospheric deposits. After measuring the fresh weight, a sample of $400 \mathrm{~g}$ of plants was dried at $80^{\circ} \mathrm{C}$ for $48 \mathrm{~h}$, and then the dry weight was measured and crushed. Since this step is highly critical since it can cause metal contamination or loss, a porcelain mortar was used to avoid contamination. Then, the samples were sieved through a nylon sieve to obtain a fine powder.
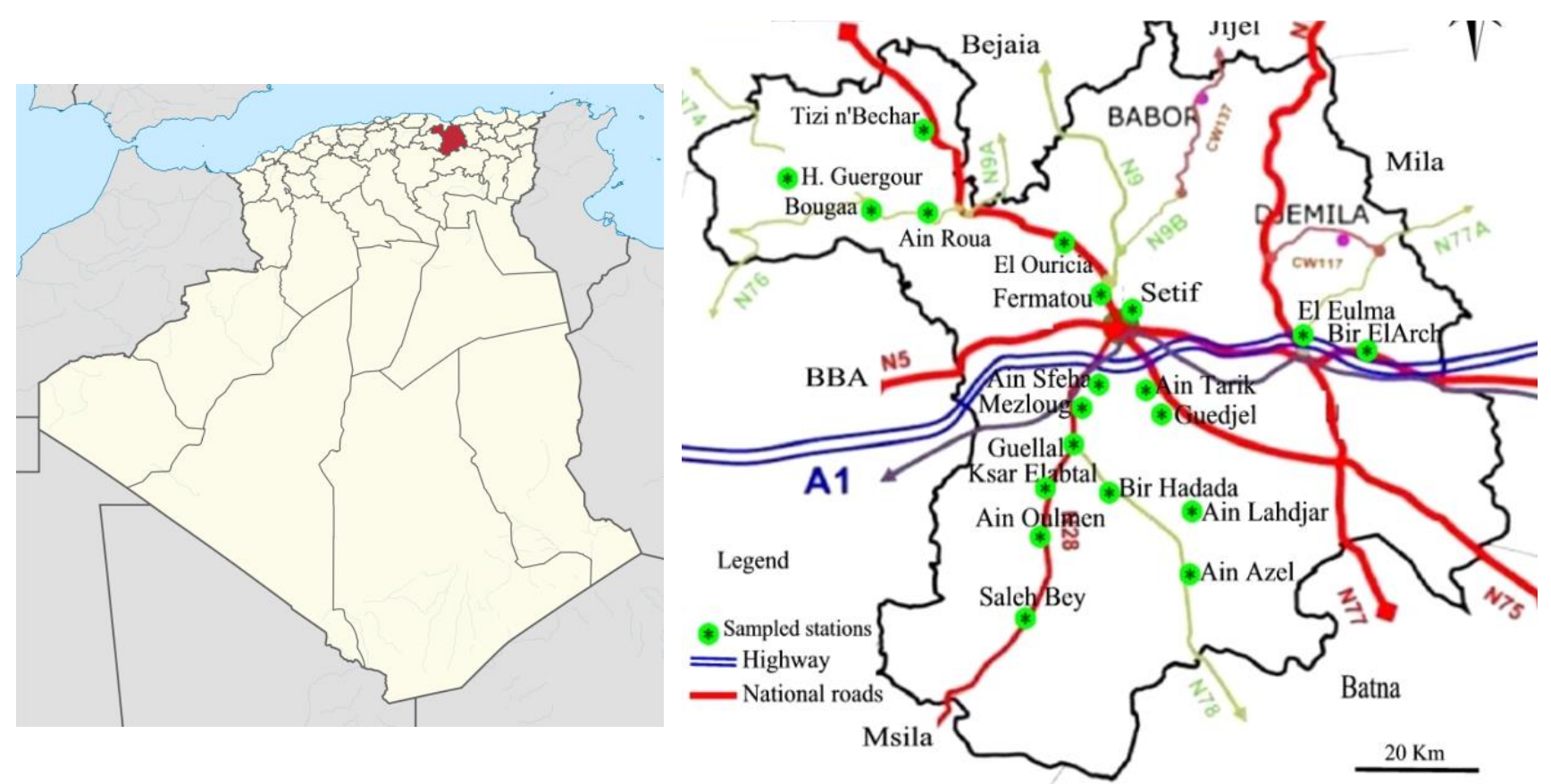

Figure 1. Observation and sampling stations for Nerium oleander populations in the province of Sétif, Algeria 
Table 1. Geographical coordinates and altitude of the sampling stations in Setif Province, Algeria

\begin{tabular}{lcccl}
\hline \multicolumn{1}{c}{ Station } & Latitude (N) & Longitude (E) & Altitude (m) & \multicolumn{1}{c}{ Sampling locations } \\
\hline Tizi n'Bechar & $36^{\circ} 43^{\prime} 55^{\prime \prime}$ & $5^{\circ} 32^{\prime} 91^{\prime \prime}$ & 881 & RN9 \\
H. Guergour & $36^{\circ} 33^{\prime} 63^{\prime \prime}$ & $5^{\circ} 04^{\prime} 99^{\prime \prime}$ & 831 & RN75 \\
Bougaa & $36^{\circ} 33^{\prime} 51^{\prime \prime}$ & $5^{\circ} 09^{\prime} 69^{\prime \prime}$ & 950 & RN75 \\
Ain Roua & $36^{\circ} 33^{\prime} 78^{\prime \prime}$ & $5^{\circ} 15^{\prime} 69^{\prime \prime}$ & 1085 & RN75; presence of quarries \\
El Ouricia & $36^{\circ} 26^{\prime} 99^{\prime \prime}$ & $5^{\circ} 40^{\prime} 2^{\prime \prime}$ & 1103 & RN9 \\
Fermatou & $36^{\circ} 20^{\prime} 54^{\prime \prime}$ & $5^{\circ} 42^{\prime \prime} 90^{\prime \prime}$ & 1110 & RN9 \\
Setif & $36^{\circ} 18^{\prime} 62^{\prime \prime}$ & $5^{\circ} 44^{\prime} 51^{\prime \prime}$ & 1115 & RN5 \\
El Eulma & $36^{\circ} 15^{\prime} 75^{\prime \prime}$ & $5^{\circ} 67^{\prime} 49^{\prime \prime}$ & 950 & Highway A1 \\
Bir Arch & $36^{\circ} 13^{\prime} 08^{\prime \prime}$ & $5^{\circ} 39^{\prime} 76^{\prime \prime}$ & 1105 & RN5 \\
Ain Sfiha & $36^{\circ} 17^{\prime} 34^{\prime \prime}$ & $5^{\circ} 39^{\prime} 76^{\prime \prime}$ & 1100 & RN28 \\
Mezloug & $36^{\circ} 10^{\prime} 65^{\prime \prime}$ & $5^{\circ} 33^{\prime} 99^{\prime \prime}$ & 933 & RN 28, Intense industry \\
Guellal & $36^{\circ} 04^{\prime} 29^{\prime \prime}$ & $5^{\circ} 33^{\prime} 84^{\prime \prime}$ & 911 & RN28, presence of quarries \\
Ksar El Abtal & $35^{\circ} 97^{\prime} 65^{\prime \prime}$ & $5^{\circ} 30^{\prime} 73^{\prime \prime}$ & 897 & RN28 \\
Ain Oulmene & $35^{\circ} 94^{\prime} 01^{\prime \prime}$ & $5^{\circ} 30^{\prime} 22^{\prime \prime}$ & 950 & RN28 \\
Saleh Bey & $35^{\circ} 51^{\prime} 04^{\prime \prime}$ & $5^{\circ} 17^{\prime} 34^{\prime \prime}$ & 978 & RN28 \\
Bir Hadada & $35^{\circ} 96^{\prime} 01^{\prime \prime}$ & $5^{\circ} 43^{\prime} 51^{\prime \prime}$ & 934 & RN78, presence of quarries, agriculture \\
Ain Lahdjar & $35^{\circ} 93^{\prime} 94^{\prime \prime}$ & $5^{\circ} 54^{\prime} 02^{\prime \prime}$ & 916 & RN78, presence of quarries \\
Ain Azel & $35^{\circ} 80^{\prime} 91^{\prime \prime}$ & $5^{\circ} 51^{\prime} 10^{\prime \prime}$ & 916 & RN78, zinc mine \\
AinTarik & $36^{\circ} 15^{\prime} 16^{\prime \prime}$ & $5^{\circ} 44^{\prime} 01^{\prime \prime}$ & 1107 & RN75, industrial area \\
Guidjel & $36^{\circ} 09^{\prime} 02^{\prime \prime}$ & $5^{\circ} 48^{\prime} 98^{\prime \prime}$ & 985 & RN75, Agriculture \\
\hline
\end{tabular}

\section{Calcination}

The method of Tauzin and Just (Belguidoum et al. 2020) was used. The resulting fine powder ( 1 to $2 \mathrm{~g}$ of leaves) was calcined using quartz capsules in a muffle oven with the temperature was gradually increased to $500^{\circ} \mathrm{C}$ from 2 hours to 4 hours.

\section{Mineralization}

The method of Tauzin and Just (Belguidoum et al. 2020) was applied to assess the metal concentration in the sample. It consisted of calcining 1 to $2 \mathrm{~g}$ of leaves in a muffle furnace at $450^{\circ} \mathrm{C}$ for four hours. The ashes obtained were mineralized by aquaregia $\left(25 \% \mathrm{HNO}_{3}\right.$ and $\left.75 \% \mathrm{HCl}\right)$ then dried on a sand bath until discoloration of the mineral deposit occurred. The residue was dissolved in $10 \mathrm{~mL} \mathrm{HCl}$ $5 \%$, and then filtered on Whatman paper with $0.45 \mu \mathrm{m}$ of diameter, and completed to $20 \mathrm{~mL}$ with $\mathrm{HCl} 5 \%$. Heavy metals were assayed using Atomic Absorption Spectrophotometer with Flame (AASF) in the laboratory of Valorization of Natural Biological Resources, Setif University.

\section{Analytical procedures for MTE concentrations}

The concentration of the following elements $(\mathrm{Cd}, \mathrm{Mn}$, $\mathrm{Pb}, \mathrm{Sb}, \mathrm{Cu}, \mathrm{Bi}$ and $\mathrm{Fe}$ ), were determined by Atomic Absorption Spectrophotometry with Flame (AASF). There are no established standards of trace element concentration in ppm. To interpret the results of each element studied, we used standard reference values according to the unit's concentration ranges. The obtained results (in $\mathrm{g} / \mathrm{L}$ ) were transformed into $\mathrm{mg} / \mathrm{kg}$ using the following relationship:

$$
T(m g / k g)=\mathrm{C} \frac{\mathrm{v}}{\mathrm{s}}
$$

Where;

$\mathrm{T}$ : element concentration in $\mathrm{mg} / \mathrm{kg}$

$\mathrm{C}$ : concentration of the element in $\mathrm{mg} / \mathrm{l}$ determined by the calibration curve

$\mathrm{V}$ : extraction volume in $\mathrm{mL}$

S: sample weight in grams

\section{Statistical analysis}

Data were first subjected to Principal Components Analysis (PCA) to examine the relationships among the trace elements and the bioaccumulation by this plant, and the relationships between the presence of these elements and the vehicle circulations. Cluster analysis using unweighted pair group method with arithmetic mean (UPGMA) was carried out on the original variables and on the Manhattan distance matrix to seek hierarchical associations among the elements and stations. The statistical analyses were carried out using STATISTICA 10 software.

\section{RESULTS AND DISCUSSION}

The results of the metallic trace elements (MTE) of Cd, $\mathrm{Mn}, \mathrm{Pb}, \mathrm{Sb}, \mathrm{Cu}, \mathrm{Bi}$, and $\mathrm{Fe}$, accumulated in the leaves of Nerium oleander from 20 stations in Setif Province, Algeria is presented in (Table 2). In general, the concentrations of MTE in the leaves vary and exceed the certified standard values.

Cadmium contents in Nerium oleander leaves varied, showing a total absence in seven stations, while the other stations had values exceeding the certified standards. The highest concentration of $\mathrm{Cd}$ was recorded in the Bir Hadada station with $99 \mathrm{mg} / \mathrm{kg}$ ). Similarly, the accumulation of Mn was very high and variable, with an 
average of $2133.5 \pm 1579.86 \mathrm{mg} / \mathrm{kg}$, thus far exceeding the certified standard of $33 \mathrm{mg} / \mathrm{kg}$. The highest level of $\mathrm{Mn}$ was also found in the Bir Hadada station with $5980 \mathrm{mg} / \mathrm{kg}$, which is probably due to the proximity of this station to agricultural activities and the presence of twelve quarries, which negatively affects the environmental quality of the region.

A strong accumulation of $\mathrm{Pb}$ was recorded with an average of $550.5 \pm 280.97 \mathrm{mg} / \mathrm{kg}$, exceeding the certified limits. The stations of Farmatou, Guidjel, and Mezoug had the highest rates of $\mathrm{Pb}$ concentration in the leaves of Nerium oleander. These stations are located in the vicinity of roads with high traffic and affected by industrial activities that use lead as material sources. In addition, a strong accumulation of iron was noted in the studied stations, particularly in Mezloug station in which this station is located near chemical industries. The Farmatou station has the highest level of Sb with $3210 \mathrm{mg} / \mathrm{kg}$. While the Bougaa station has the lowest rate of this element. The accumulation of elements $(\mathrm{Fe}, \mathrm{Cu}, \mathrm{Bi}$, and $\mathrm{Sb})$ in the leaves of $N$. oleander, reveal values exceeding the certified standards, with high averages. The rank of metallic trace elements analyzed in this study based on the averages is $\mathrm{Mn}>\mathrm{Sb}>\mathrm{Bi}>\mathrm{Pb}>\mathrm{Fe}>\mathrm{Cu}>\mathrm{Cd}$.

The results reveal a significant variation in MTE among the stations studied and among the concentrations of MTE.
The accumulation of $\mathrm{Sb}$ and $\mathrm{Mn}$ was very high in the stations studied, particularly at Bir Hadada, Farmatou, and Mezloug. These results show that this species is a hyperaccumulation of $\mathrm{Sb}$ and $\mathrm{Mn}$.

The MTE concentrations varied across the sampled stations. The Mn element shows the greatest variability in $N$. oleander populations, while the $\mathrm{Cd}$ level is the least variable (Figure 2).

UPGMA statistical analysis of the results shows that MTE are separated into two clusters. The first cluster includes the elements of $\mathrm{Sb}$ and $\mathrm{Mn}$ in which their concentrations were very high in all populations. The second cluster brings together two groups. The elements of $\mathrm{Bi}$ and $\mathrm{Pb}$ from the first group with high to medium concentrations, while $\mathrm{Cd}, \mathrm{Cu}$, and $\mathrm{Fe}$ form the second group with more or less low concentrations (Figure 3). This analysis confirms the results of the classification of MTE $\mathrm{Mn}>\mathrm{Sb}>\mathrm{Bi}>\mathrm{Pb}>\mathrm{Fe}>\mathrm{Cu}>\mathrm{Cd}$.

Based on the first three axes from the PCA, the threedimensional spatial projection of the stations shows the formation of a point cloud with the individualization of three populations (Fermatou, Mesloug, and Bir Hadada) (Figure 4). High rates of MTE characterize these three populations. The remaining populations are a group where the populations were not individualized

Table 2. MTE concentration in Nerium oleander leaves ( $\mathrm{mg} / \mathrm{kg}$ ) across 20 observation stations in Setif Province, Algeria

\begin{tabular}{|c|c|c|c|c|c|c|c|}
\hline Stations & Cd & Mn & $\mathbf{P b}$ & $\mathbf{S b}$ & $\mathrm{Cu}$ & $\mathbf{B i}$ & $\mathbf{F e}$ \\
\hline Tizi n'Béchar & 26 & 910 & 230 & 1630 & 55 & 850 & 220 \\
\hline H. Guergour & 0 & 770 & 530 & 2880 & 80 & 680 & 200 \\
\hline Ain Roua & 60 & 2510 & 610 & 2586 & 208 & 760 & 210 \\
\hline EL Ouricia & 30 & 1750 & 510 & 2580 & 920 & 780 & 200 \\
\hline Farmatou & 0 & 4930 & 1550 & 3210 & 590 & 660 & 150 \\
\hline El Eulma & 3 & 2520 & 460 & 2270 & 105 & 680 & 610 \\
\hline Bir Arch & 0 & 2700 & 670 & 1450 & 152 & 850 & 90 \\
\hline Ain Sfiha & 30 & 1070 & 330 & 1380 & 98 & 920 & 240 \\
\hline Mezloug & 0 & 4900 & 660 & 1350 & 800 & 800 & 3070 \\
\hline Guellal & 0 & 1120 & 470 & 1940 & 670 & 670 & 370 \\
\hline Kasr El Abtal & 3 & 640 & 520 & 2600 & 850 & 850 & 230 \\
\hline Ain Oulmen & 5 & 2790 & 550 & 2060 & 240 & 1000 & 23 \\
\hline Bir Hadada & 99 & 5980 & 500 & 1830 & 600 & 850 & 370 \\
\hline Ain Lahdjar & 0 & 980 & 450 & 2350 & 149 & 620 & 150 \\
\hline Ain Azel & 62 & 1060 & 310 & 1590 & 144 & 850 & 310 \\
\hline Ain Trik & 43 & 2530 & 390 & 2250 & 360 & 700 & 180 \\
\hline Guidjel & 39 & 2910 & 900 & 2160 & 240 & 890 & 470 \\
\hline Average & 23.2 & 2133.5 & 550.5 & 2068.3 & 333.15 & 788.5 & 376.65 \\
\hline SD & 27.67 & 1579.9 & 280.97 & 573.55 & 289.37 & 107.37 & 648.73 \\
\hline RSD & 119.26 & 74.1 & 51.04 & 27.73 & 86.86 & 13.62 & 172.24 \\
\hline Min. & 0 & 560 & 230 & 1250 & 55 & 620 & 23 \\
\hline Max. & 99 & 5980 & 1550 & 3210 & 920 & 920 & 3070 \\
\hline Certified standards & 0.6 & 33 & 40.9 & 0.35 & 7.03 & 4.12 & 804 \\
\hline
\end{tabular}


The result of UPGMA analysis shows the heterogeneity of the accumulation of MTE in $N$. oleander across stations and confirms the separation of populations studied into two groups (Figure 5). The first group is represented by the stations of Mezloug, Farmatou and Bir Hadada, characterized by a strong accumulation of MTE in the leaves; particularly $\mathrm{Mn}$ and $\mathrm{Sb}$. These stations have high levels of pollution from MTE. These high rates are probably due in large part to the region's significant agricultural activities and some industrial activities. While the second group is divided into two branches. The stations of Bir Arch, Ain Roua, El Eulma, Gudjel, Ain Trik, and Ain Oulmen represent the first sub-branch, with a high accumulation of MTE. The second sub-branch, includes the least polluted stations, still, the MTE accumulation rate is much higher than the standard values. In contrast, the populations of Tizi n'Bechar accumulate low concentrations of MTE, with the lowest $\mathrm{Cu}$ concentration compared to the different stations studied $(55 \mathrm{mg} / \mathrm{kg})$.

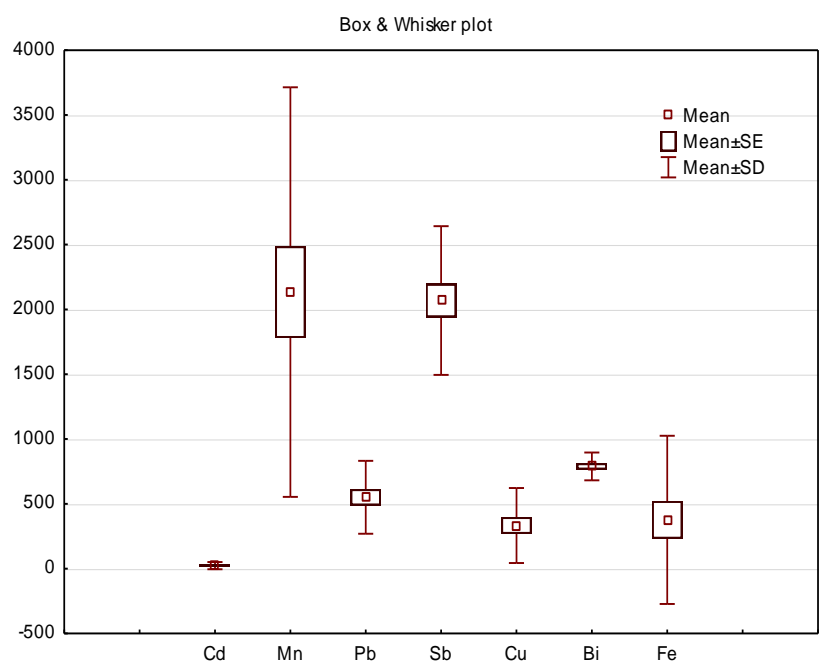

Figure 2. Variability of MTE concentrations in Nerium oleander leaves in Setif Province, Algeria
Unweighted pair-group av erage; City-block (Manhattan) distances

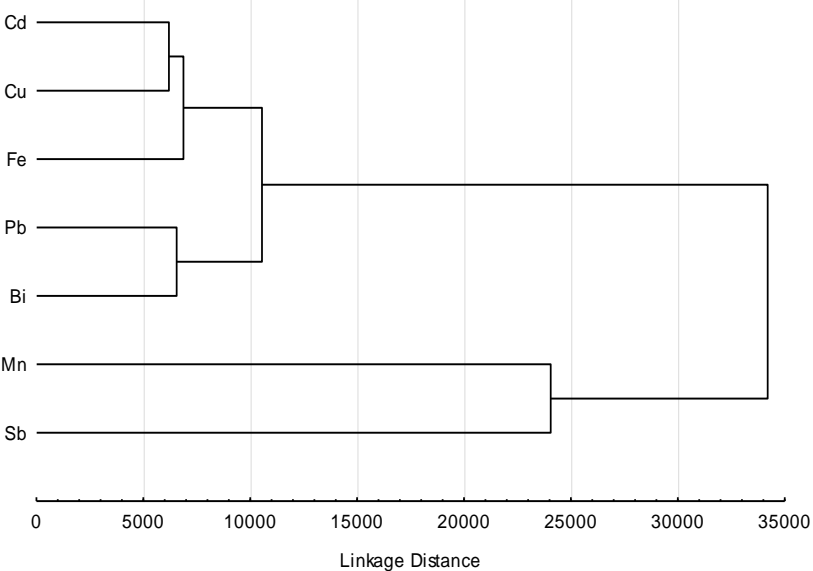

Figure 3. The clustering analysis of MTE accumulations in the leaves of N. oleander in Setif Province, Algeria

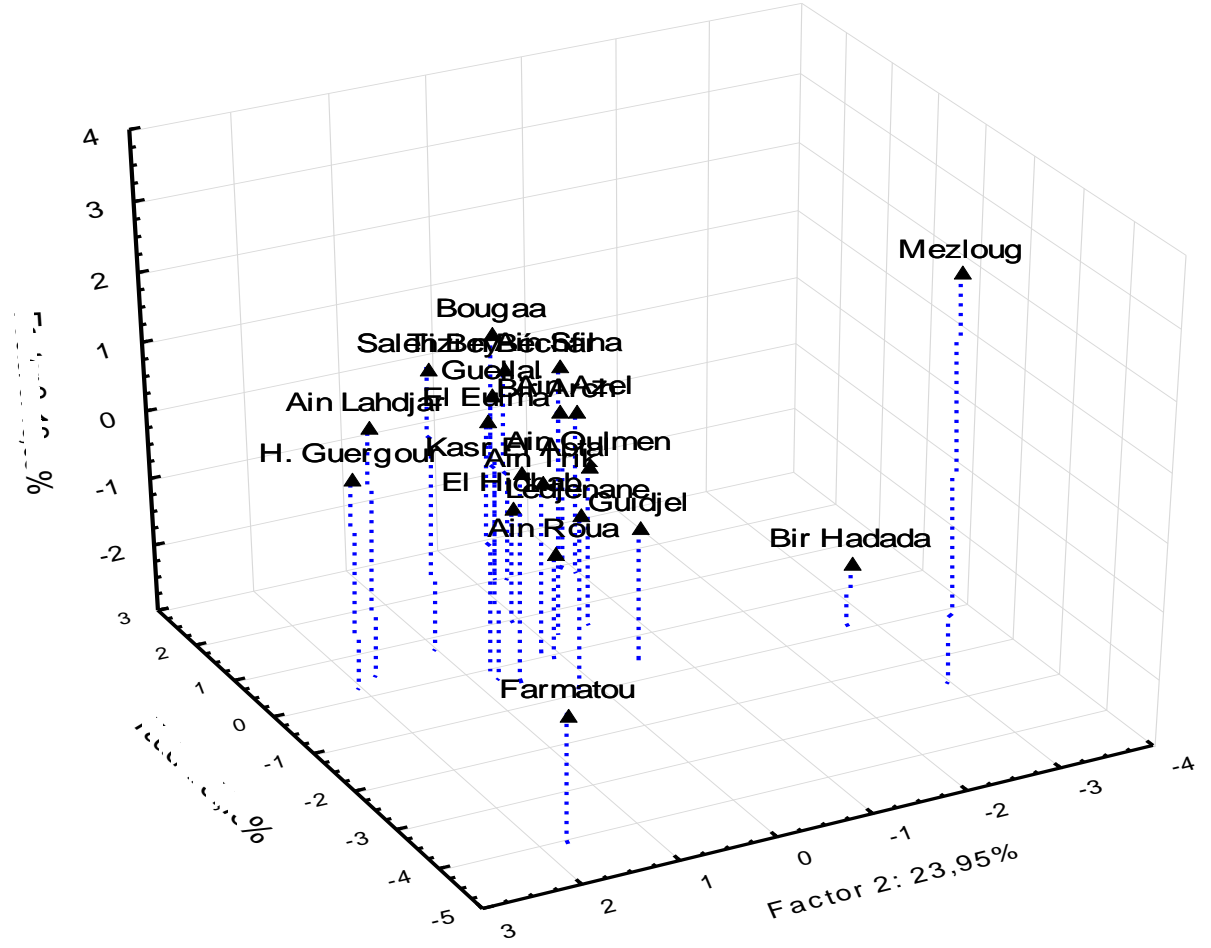

Figure 4. Spatial projection of stations based on the first three axes of the PCA 
Unweighted pair-group av erage; City-block (Manhattan) distances

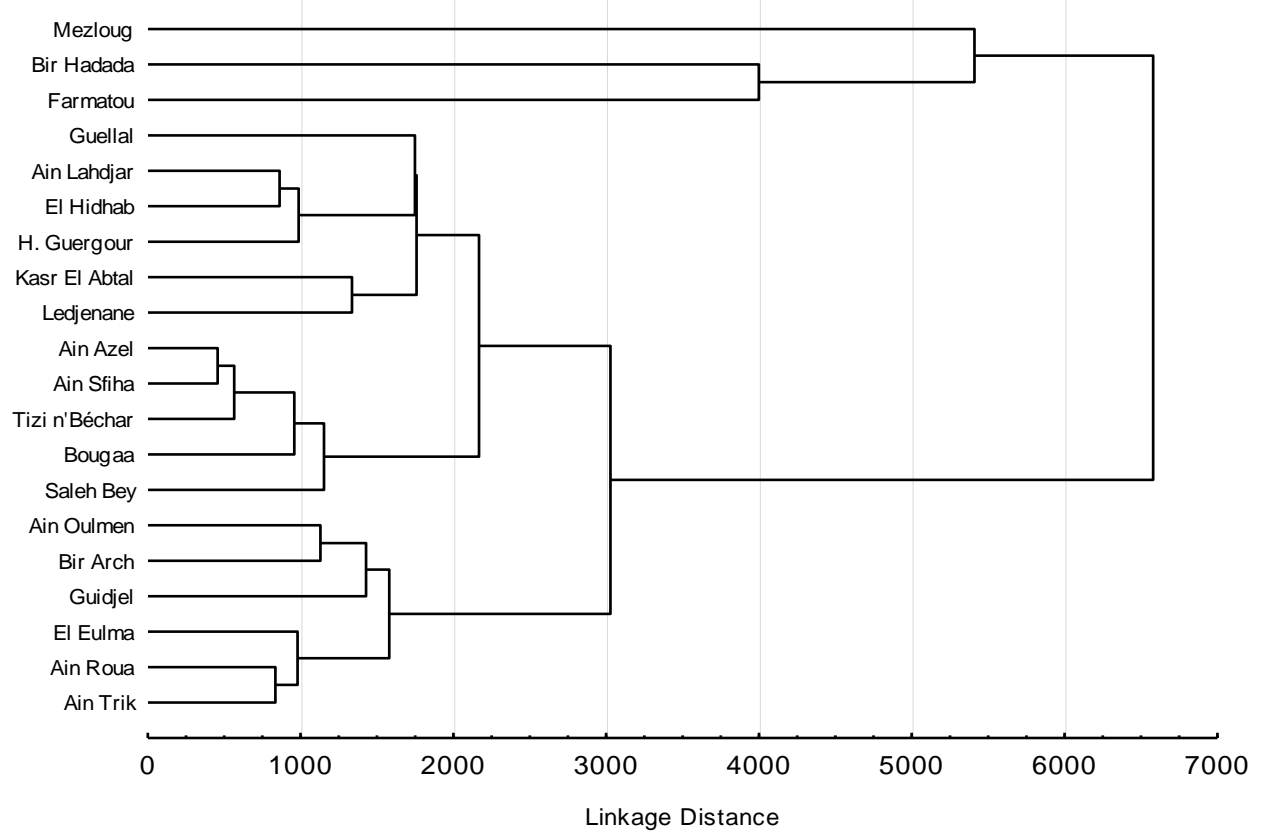

Figure 5. The clustering analysis of twenty Nerium oleander populations in Setif Province, Algeria based on MTE concentration

\section{Discussion}

Trace metallic elements (MTE) from natural and anthropogenic sources degrade the initial state of urban environment (Aksu 2015; Linderholm 2015; Chen et al. 2016; Hodomihou et al. 2016; Pichtel 2016; Iqbal et al. 2016; Yan et al. 2020) as observed in the study region. The concentration of MTE accumulated by Nerium oleander in Setif Province, Nigeria shows the rank in concentration of the elements $\mathrm{Mn}>\mathrm{Sb}>\mathrm{Bi}>\mathrm{Pb}>\mathrm{Fe}>\mathrm{Cu}>\mathrm{Cd}$. Other studies on the concentration of MTE in the leaves of $N$. oleander have revealed similar results (Espinosa and Oliva 2006; Mingorance and Oliva 2006; Mingorance et al. 2007; Santos et al. 2019; Fliou et al. 2020; Ibrahim and El Afandi 2020a).

The evaluation of the levels of MTE accumulation in the leaves of $N$. oleander shows extremely high values. In general, the concentrations of these elements are closely linked to intensive agricultural activities, which is in accordance with other observations (Abbasi et al. 2014; Song et al. 2020; Theo et al. 2020). Similarly, severe emissions from metallurgical industrial activities in the region also contribute to the increase of these elements in the environment (Hu et al. 2014; González-Castanedo et al. 2014; Pollard et al. 2015).

The MTE concentrations in the leaves of $N$. oleander show a strong accumulation in the Bir Hadada station. This accumulation is probably due to the various quarries surrounding the study station, which is located between two mountains, i.e., Djebel Sakreen to the south and Djebel Youssef to the north. Overall, the region has 12 quarries, which might negatively affect the environment (Issah et al. 2010; Midhat et al. 2019; Rimondi et al. 2020). The high rates of MTE accumulation at Bir Hadada is presumably not only linked to a large number of quarries, but also related emissions from intensive agricultural operations which degrade the environment through the release of pesticides and chemicals that generate associated toxic heavy metal particles suspended in the environment (Wei and Yang. 2010; Vázquez et al. 2016; Kirpik et al. 2017; Oumenskou et al. 2018).

This study is consistent with the results of other works, showing the relationship between the presence of MTE in the environment and their bioaccumulation in higher plants (Kabata-Pendias and Pendias 2001; Mohamed et al. 2013; Nguyen-Van et al, 2016; Ibrahim and El Afandi. 2020b). The concentrations of $\mathrm{Sb}, \mathrm{Mn}, \mathrm{Cu}$ and $\mathrm{Pb}$ were high at stations located near roads. The high levels of these elements have been positively correlated with the traffic because vehicle exhaust emissions have a significant role in environmental contamination (De Silva et al. 2016; Kirpik et al. 2017; Yang et al. 2020). Studies on the accumulation of MTE by the plants located in the proximity roads showed a close relationship between levels of heavy metals and the volume of traffic (De Silva et al. 2016; Yang et al. 2020; Belguidoum et al. 2021). In Turkey, Nerium oleander has been used as a biomonitor tool for heavy metal accumulation in intense human activity and heavy road traffic (Banu-Doganlar et al. 2012).

The Mezloug station reveals a high level of iron due to the transport of airborne particles from the chemical industry area, which contributes significantly to this pollution (Odabasi et al. 2010). The plants accumulate more heavy metals in industrial areas than in agricultural areas (Hanedar 2015). Lograda et al. (2016) and Belguidoum et al. (2020) have reported the same observations. 
The concentrations of $\mathrm{Cd}$ and $\mathrm{Pb}$ far exceed the standard values in the Ain Azel station, which is in accordance with the findings of Lograda et al. (2016) and Belguidoum et al. (2020). The high levels of these elements are probably associated with mining the Kherzet Youcef polymetallic deposit, which constitutes a significant source of environmental contamination (Bellouche 2016; DanBadjo et al. 2019). In Morocco mining areas, Duraes et al. (2015) found the presence of high levels of $\mathrm{Pb}$ and $\mathrm{Cu}$ in the leaves of $N$. oleander. Similar observations have been made in Spain on the oleander plant in extremely acidic mine drainage environments (Franco et al. 2013). Therefore, the establishment of a monitoring and treatment program for soil and polluted water in mining stations would be necessary to preserve human health (Dan-Badjo et al. 2019).

The concentration of MTE accumulated in the $N$. oleander leaves exceeds the certified standards. This condition is related to the biogenic capacity of the plant, which produces chemical chelators favoring the accumulation of these elements (Elloumi et al. 2017; Suba et al. 2018). The evaluation of the kinetics of some MTE in $N$. oleander seedlings by Franco et al. (2013) shows a high level of $\mathrm{Mn}, \mathrm{Fe}$, and $\mathrm{Cu}$ in Nerium seedlings, which confirms our results. The super accumulating plants of MTE can be used for the bioremediation of the environment polluted by these heavy metals (Morel 2002, Ali et al. 2013; Haq et al. 2020; Morel 2021). Therefore, $N$. oleander can be considered as a hyper-accumulator of metals with a high tolerance to $\mathrm{Mn}, \mathrm{Sb}$ and $\mathrm{Pb}$, thus offering prospects for application to phytoremediation in large polluted urban geographic areas.

In conclusion, the study results provide an assessment of the pollution in Setif region by using the concentration of heavy metals of $\mathrm{Cd}, \mathrm{Mn}, \mathrm{Pb}, \mathrm{Sb}, \mathrm{Cu}, \mathrm{Bi}$ and $\mathrm{Fe}$ in Nerium oleander leaves. It was shown that the sampled stations were heavily polluted by the presence of high levels of MTE. Overall, the MTE concentrations were higher than the standards with $\mathrm{Mn}$ and $\mathrm{Sb}$ concentrations greatly exceeded the certified standards. The element of $\mathrm{Mn}$ was found to be the highest and $\mathrm{Cd}$ was the lowest according to the sequence of $\mathrm{Mn}>\mathrm{Sb}>\mathrm{Bi}>\mathrm{Pb}>\mathrm{Fe}>\mathrm{Cu}>$ Cd. Tizi n'Bechar can be considered as the less polluted site, while Mezloug, Bir Hadada and Fermatou were the most polluted sites with high human activity and vehicular density. The results indicate a good agreement between the concentrations of heavy metals in $N$. oleander and the anthropic impacts, which are notably represented by mining, agricultural activities, chemical industries, and the combustion processes linked to vehicle emissions. The results suggest that Nerium oleander can be used as a bioaccumulator of MTE in soil pollution monitoring studies, thus offering prospects for application in phytoremediation. We thus propose the use of Nerium oleander in the rehabilitation of the polluted urban landscape to minimize the impact of pollution, and simultaneously enrich the landscape without altering the ecosystem.

\section{ACKNOWLEDGEMENTS}

The source financials for the work are provided by MESRS of Algeria (Project Code No. D01N01UN190120200005), and no potential conflicts of interest.

\section{REFERENCES}

Abbasi A, Sajid A, Haq N, Rahman S, Misbah ZT, Sanober G, Kazi AG. 2014. Agricultural pollution: An emerging issue. In: Improvement of crops in the era of climatic changes. Springer, New York. DOI: 10.1007/978-1-4614-8830-9_13.

Aksoy A, Ozturk MA. 1997. Nerium oleander L. as a biomonitor of lead and other heavy metal pollution in Mediterranean environments. Sci Total Environ 205: 145-150. DOI: 10.1016/S0048-9697(97)00195-2.

Aksu A. 2015. Sources of metal pollution in the urban atmosphere (A case study: Tuzla, Istanbul). J Environ Health Sci Engineer 13: 79. DOI: 10.1186/s40201-015-0224-9.

Ali H, Khan E, Sajad, M. A. 2013. Phytoremediation of heavy metalsconcepts and applications. Chemosphere 91 (7): 869-881. DOI: 10.1016/j.chemosphere.2013.01.075.

Al-Khlaifat AL, Al-Khashman OA. 2007. Atmospheric heavy metal pollution in Aqaba city, Jordan, using Phoenix dactylifera L. leaves. Atmospheric Environ 41 (39): 8891-8897. DOI: 10.1016/j.atmosenv.2007.08.028.

Antonucci A, Vitali M, Avino P, Manigrasso M, Protano C. 2016. Sensitive multi-residue method by HS-SPME/GC-MS for 10 volatile organic compounds in urine matrix: A new tool for biomonitoring studies on children. Anal Bioanal Chem 408: 5789-5800. DOI: 10.1007/s00216-016-9682-X.

Ashraf S, Ali Q, Zahir ZA, Ashraf S, Asghar HN. 2019. Phytoremediation: Environmentally sustainable way for reclamation of heavy metal polluted soils. Ecotoxicol Environ Safety 174: 714727. DOI: 10.1016/j.ecoenv.2019.02.068

Banu-Doganlar Z, Doganlar O, Erdogan S, Onal Y. 2012. Heavy metal pollution and physiological changes in the leaves of some shrub, palm and tree species in urban areas of Adana, Turkey. Chem Speciation $\begin{array}{llll}\text { Bioavailability } & 24 & (2): & 65-78 .\end{array}$ $10.3184 / 095422912 X 13338055043100$.

Barış Özel H, Ucun Özel H, Varol T. 2015. Using leaves of oriental plane (Platanus orientalis L.) to determine the effects of heavy metal pollution caused by vehicles. Polish J Environ Stud 24 (6): 25692575. DOI:10.15244/PJOES/59072.

Belguidoum A, Lograda T, Ramdani M. 2020. Heavy metals accumulation in Hertia cheirifolia along the highway in Setif region, $\begin{array}{llll}\text { Algeria. Biodiversitas } 21 & \text { (6): 2786-2793. DOI: }\end{array}$ $10.13057 /$ biodiv/d210655

Belguidoum A, Lograda T, Ramdani M. 2021. Ability of metal trace elements accumulation by Lichens, Xanthoria parietina and Ramalina farinacea, in Megres area (Setif, Algeria). Sciendo 8 (1): 91-108. DOI: $10.2478 /$ asn-2021-0008

Bellouche M. 2016. Schema hydrogeologique possible de la mine de Kerzet youssef (Nord-est Algerien). Sci Technol 44: 73-80.

Berlizov AN, Blum OB, Filby RH, Malyuk IA, Tryshyn VV. 2007. Testing applicability of black poplar (Populus nigra L.) bark to heavy metal air pollution monitoring in urban and industrial regions. Sci Total Environ $372 \quad(2-3)$ : 693-706. DOI: 10.1016/j.scitotenv.2006.10.029.

Chen B, Stein AF, Castell N, Gonzalez-Castanedo Y, de la Campa AS, De La Rosa JD. 2016. Modeling and evaluation of urban pollution events of atmospheric heavy metals from a large $\mathrm{Cu}$-smelter. Sci Total Environ 539: 17-25. DOI: 10.1016/j.scitotenv.2015.08.117.

Dan-Badjo AT, Ibrahim OZ, Guéro Y, Morel JL, Feidt C, Echevarria G. 2019. Impacts of artisanal gold mining on soil, water and plant contamination by trace elements at Komabangou, Western Niger. J Geochem Explor 205: 106328. DOI: 10.1016/j.gexplo.2019.06.010.

De Silva S, Ball AS, Huynh T, Reichman SM. 2016. Metal accumulation in roadside soil in Melbourne, Australia: Effect of road age, traffic density and vehicular speed. Environ Pollut 208: 102-109. DOI: 10.1016/j.envpol.2015.09.032. 
Di Lonardo S, Capuana M, Arnetoli M, Gabbrielli R, Gonnelli C. 2011. Exploring the metal phytoremediation potential of three Populus alba L. clones using an in vitro screening. Environ Sci Pollut Res 18 (1): 82-90. DOI: $10.1007 / \mathrm{s} 11356-010-0354-7$

Duraes N, Bobos I, Ferreira da Silva E, Dekayir A. 2015. Copper, zinc and lead biogeochemistry in aquatic and land plants from the Iberian Pyrite Belt (Portugal) and north of Morocco mining areas. Enviro Sci Pollut Res 22: 2087-2105. DOI: 10.1007/s11356-014-3394-6.

Elloumi N, Belhaj D, Mseddi S, Zouari M, Abdallah FB, Woodward S, Kallel M. 2017. Response of Nerium oleander to phosphogypsum amendment and its potential use for phytoremediation. Ecological Engineer 99: 164-171. DOI: 10.1016/j.ecoleng.2016.11.053.

Ernst WHO. 2003. The use of higher plants as bioindicators. Trace Metals Contaminants Environ 6: 423-463. DOI: $10.1016 / \mathrm{S} 0927-$ 5215(03)80142-X.

Farahat E, Linderholm HW. 2015. The effect of long-term wastewater irrigation on accumulation and transfer of heavy metals in Cupressus sempervirens leaves and adjacent soils. Sci Total Environ 512-513: 17. DOI: 10.1016/j.scitotenv.2015.01.032

Fioravanti S, Cesaroni G, Badaloni C, Michelozzi P, Forastiere F, Porta D. 2018. Traffic-related air pollution and childhood obesity in an Italian birth cohort. Environ Res 160: 479-486. DOI 10.1016/j.envres.2017.10.003

Fliou J, Riffi O, Amechrouq A, Elhourri M, El Idrissi M, Ahlafi H, Lhachimi Z. 2020. Phytochemical screening and analysis of heavy metals of Nerium oleander (L.) leaves. Mediterranean J Chem 10 (4) 346-354. DOI: $10.13171 / \mathrm{mjc} 10402004201366 \mathrm{aa}$

Franco A, Rufo L, Zuluaga J, de la Fuente V. 2013. Metal uptake an distribution in cultured seedlings of Nerium oleander L. (Apocynaceae) from the Río Tinto (Huelva, Spain). Biol Trace Element Res 155 (1): 82-92. DOI: 10.1007/s12011-013-9761-1.

Gharzouli R. 2007. Flore et végétation de la kabylie des babors: étude floristique et phytosociologique des groupements forestiers et postforestiers des djebels Takoucht, Adrar ou-Mellal, Tababort et Babor. Univ Sétif, Algeria.

González-Castanedo Y, Moreno T, Fernández-Camacho R, de la Campa AMS, Alastuey A, Querol, X, Rosa J. 2014. Size distribution and chemical composition of particulate matter stack emissions in and around a copper smelter. Atmospheric Environ 98: 271-282. DOI 10.1016/j.atmosenv.2014.08.057

Hanedar A. 2015. Assessment of airborne heavy metal pollution in soil and lichen in the Meric-Ergene Basin, Turkey. Environ Technol 36 (20): 2588-2602. DOI: 10.1080/09593330.2015.1039071

Hankey S, Marshall JD. 2017. Urban form, air pollution, and health. Curr Environ Health Rep 4 (4): 491-503. DOI: 10.1007/s40572-017-0167-

Haq S, Bhatti AA, Dar ZA, Bhat SA. 2020. Phytoremediation of heavy metals: An eco-friendly and sustainable approach. In: Hakeem K, Bhat R, Qadri H. (eds) Bioremediation and Biotechnology. Springer, Cham. DOI: 10.1007/978-3-030-35691-0_10.

Hodomihou NR, Feder F, Masse D, Agbossou EK, Amadji GL, NdourBadiane Y, Doelsch E. 2016. Diagnostic de contamination des agrosystèmes périurbains de Dakar par les éléments traces métalliques. Biotechnologie, Agronomie, Société et Environnement 20 (3) : 397-407. DOI: 10.25518/1780-4507.13035.

Hu H, Jin Q, Kavan P. 2014. A study of heavy metal pollution in China: Current status, pollution-control policies and countermeasures. Sustainability 6 (9): 5820-5838. DOI: $10.3390 /$ su6095820.

Ibrahim N, El Afandi G. 2020a. Evaluation of the phytoremediation uptake model for predicting heavy metals $(\mathrm{Pb}, \mathrm{Cd}$, and $\mathrm{Zn}$ ) from the soil using Nerium oleander L. Environ Sci Pollut Res 27 (30): 3812038133. DOI: $10.1007 / \mathrm{s} 11356-020-09657-5$.

Ibrahim Naira, Gamal El Afandi. 2020b. Phytoremediation uptake model of heavy metals $(\mathrm{Pb}, \mathrm{Cd}$ and $\mathrm{Zn})$ in soil using Nerium oleander, Heliyon 6: e04445. DOI: 10.1016/j.heliyon.2020.e04445.

Iqbal M, Iqbal N, Bhatti IA, Ahmad N, Zahid M. 2016. Response surface methodology application in optimization of cadmium adsorption by shoe waste: A good option of waste mitigation by waste. Ecol Engineer 88: 265-275. DOI: 10.1016/j.ecoleng.2015.12.041.

Issah AS, Djangbedja M, Mawussi G, Gnandi K, Tchamie TTK. 2016. Evaluation de la pollution des sols de la carriere de calcaire de tabligbo (sud-est togo) par les metaux lourds toxiques. Cahiers du CBRST 10: 1-18

Kabata-Pendias A, Pendias H. 2001. Trace elements in soils and plants, $3^{\text {rd }}$ Ed. CRC Press, Boca Raton.
Kirpik M, Büyük G, Gnan M, Celg̈k A. 2017. The heavy metal content of some herbal plants on the roadside of Adana-Gaziantep highway. J Agric Faculty of Gaziosmanpasa University 34: 129-136.

Lodenius M, Kiiskinen J, Tulisalo E. 2010. Metal levels in an epiphytic lichen as indicators of air quality in a suburb of Helsinki, Finland. Boreal Environ Res 15 (4): 446-452.

Lograda T, Harkati Z, Adel K, Ramdani M. 2016. Heavy metals accumulation in species from mine Karzet Youcef (Algeria). Word J Pharmaceut Res 5 (11): 250-260.

Maher BA, Moore C, Matzka J. 2008. Spatial variation in vehicle-derived metal pollution identified by magnetic and elemental analysis of roadside tree leaves. Atmospheric Environ 42 (2): 364-373. DOI: 10.1016/j.atmosenv.2007.09.013

Midhat L, Ouazzani N, Hejjaj A, Ouhammou A, Mandi L. 2019. Accumulation of heavy metals in metallophytes from three mining sites (Southern Centre Morocco) and evaluation of their phytoremediation potential. Ecotoxicol Environ Safety 169: 150-160. DOI: 10.1016/j.ecoenv.2018.11.009

Mingorance MD, Oliva SR. 2006. Heavy metals content in $N$. oleander leaves as urban pollution assessment. Environ Monit Assess 119 (1): 57-68. DOI: $10.1007 / \mathrm{s} 10661-005-9004-9$

Mingorance MD, Valdes B, Oliva SR. 2007. Strategies of heavy metal uptake by plants growing under industrial emissions. Environ Int 33 (4): 514-520. DOI: 10.1016/j.envint.2007.01.005

Mohamed M, Mokhtar A, Dahbia Z, Mohamed AH. 2013. Decontamination of Agricultural Soil Polluted with Lead using the Common Barley (Hordeum vulgare). Arab Gulf J Sci Res 31 (1): 2335 .

Morel JL. 2002. La phytoremédiation des sols contaminés. L'Actualité Chimique 1 (Special): 63-66.

Morel JL. 2021. Chapitre 8: Phytoremédiation des sols contaminés: des plantes pour guérir les sols. In La chimie et la nature. EDP Sci 157184. DOI: 10.1051/978-2-7598-0859-5-011.

Napoli M, Cecchi S, Grassi C, Baldi A, Zanchi CA, Orlandini S. 2019. Phytoextraction of copper from a contaminated soil using arable and vegetable crops. Chemosphere 219: 122-129. DOI: 10.1016/j.chemosphere.2018.12.017

Nguyen-Van T, Ozaki A, Nguyen Tho H, Nguyen Duc A, Tran Thi Y, Kurosawa K. 2016. Arsenic and heavy metal contamination in soils under different land use in an estuary in Northern Vietnam. Int J Environ Res Public Health 13 (11): 1091. DOI: 10.3390/ijerph13111091.

Nordberg GF, Fowler BA, Nordberg M. 2015. Toxicology of metals: Overview, definitions, concepts, and trends. Handbook Toxicol Metals 1: 1-12. DOI: 10.1016/B978-0-444-59453-2.00001-9.

Odabasi M, Bayram A, Elbir T, Seyfioglu R, Dumanoglu Y, Ornektekin S. 2010. Investigation of soil concentrations of persistent organic pollutants, trace elements, and anions due to iron-steel plant emissions in an industrial region in Turkey. Water, Air, Soil Pollut 213 (1): 375-388. DOI: 10.1007/s11270-010-0392-2.

Oumenskou H, El Baghdadi M, Barakat A, Aquit M, Ennaji W, Karroum LA, Aadraoui M. 2018. Assessment of the heavy metal contamination using GIS-based approach and pollution indices in agricultural soils from Beni Amir irrigated perimeter, Tadla plain, Morocco. Arabian J Geosci 11 (22): 1-18. DOI: 10.1007/s12517-018-4021-5.

Pandey B, Agrawal M, Singh S. 2014. Assessment of air pollution around coal mining area: Emphasizing on spatial distributions, seasonal variations and heavy metals, using cluster and principal component analysis. Atmospheric Pollut Res 5 (1): 79-86. DOI: 10.5094/apr.2014.010.

Parzych A, Astel A, Zduńczyk A, Surowiec T. 2016. Evaluation of urban environment pollution based on the accumulation of macro-and trace elements in epiphytic lichens. J Environ Sci Health Part A 51 (4): 297-308. DOI: 10.1080/10934529.2015.1109387.

Pichtel J. 2016. Oil and gas production wastewater: Soil contamination and pollution prevention. Appl Environ Soil Sci 2016: 2707989. DOI: $10.1155 / 2016 / 2707989$

Pirintsos SA, Loppi S. 2008. Biomonitoring atmospheric pollution: The challenge of times in environmental policy on air quality. Environ Pollut 151: 269-171. DOI: 10.1016/j.envpol.2007.06.035.

Pollard AS, Williamson BJ, Taylor M, Purvis WO, Goossens M, Reis S, Osborne NJ. 2015. Integrating dispersion modelling and lichen sampling to assess harmful heavy metal pollution around the Karabash copper smelter, Russian Federation. Atmospheric Pollut Res 6 (6): 939-945. DOI: 10.1016/j.apr.2015.04.003. 
Rimondi V, Benesperi R, Beutel MW, Chiarantini L, Costagliola P, Lattanzi P, Morelli G. 2020. Monitoring of airborne mercury: Comparison of different techniques in the Monte Amiata District, Southern Tuscany, Italy. Intl J Environ Res Public Health 17 (7) 2353. DOI: 10.3390/ijerph17072353.

Santos RS, Sanches FA, Leitão RG, Leitão CC, Oliveira DF, Anjos MJ, Assis JT. 2019. Multi-elemental analysis in Nerium Oleander L. leaves as a way of assessing the levels of urban air pollution by heavy metals. Appl Radiation Isotopes 152: 18-24. DOI: 10.1016/j.apradiso.2019.06.020.

Schreck E, Leveque T, Pradere P, Dumat C. 2012. Vers une gestion raisonnée des terres excavées contaminées par des éléments traces métalliques (ETM). Environnement, Risques and Santé 11 (1): 61-66. DOI: 10.1684/ers.2011.0506.

Sivakumar S, Prabha D, Velmurugan P, Hong SC, Yi PI, Jang, SH, Suh JM. 2020. Phytoremediation of $\mathrm{Cu}$ and $\mathrm{Cd}$-contaminated roadside soils by using stem cuttings of Portulaca oleracea L. Environ Chem Ecotoxicol 2: 201-204. DOI: 10.1016/j.enceco.2020.10.004.

Song C, Sarpong CK, He J, Shen F, Zhang J, Yang G, Deng S. 2020. Accelerating phytoremediation of degraded agricultural soils utilizing rhizobacteria and endophytes: A review. Environ Rev 28 (1): 115 127. DOI: 10.1139/er-2019-0020.

Speak AF, Rothwell JJ, Lindley SJ, Smith CL. 2012. Urban particulate pollution reduction by four species of green roof vegetation in a UK city. Atmospheric Environ 61: 283-293. DOI: 10.1016/j.atmosenv.2012.07.043.

Stamenkovic SS, Mitrovic TL, Cvetkovic VJ, Krstic NS, Baosic R, Markovic MS, Cvijan MV. 2013. Biological indication of heavy metal pollution in the areas of Donje Vlase and Cerje (Southeastern Serbia) using epiphytic lichens. Archive Biol Sci 5 (1): 151-159. DOI: 10.2298/ABS1301151S.

Suba V, Rathika G, Kumar ER, Saravanabhavan M. 2018. Influence of magnetic nanoparticles on surface changes in $\mathrm{CoFe}_{2} \mathrm{O}_{4} /$ Nerium Oleander leaf waste activated carbon nanocomposite for water treatment. J Inorg Organomet Polymers Materials 28 (5): 1706-1717. DOI: $10.1007 / \mathrm{s} 10904-018-0831-\mathrm{x}$.

Suman J, Uhlik O, Viktorova J, Macek T. 2018. Phytoextraction of heavy metals: a promising tool for clean-up of polluted environment?. Front Plant Sci 9: 1476. DOI: 10.3389/fpls.2018.01476.
Tallis M, Taylor G, Sinnett D, Freer-Smith P. 2011. Estimating the removal of atmospheric particulate pollution by the urban tree canopy of London, under current and future environments. Landscape Urban Planning 103 (2): 129-138. DOI: 10.1016/j.landurbplan.2011.07.003.

Tchounwou PB, Yedjou CG, Patlolla AK, Sutton DJ. 2012. Heavy metal toxicity and the environment. Mol Clin Environ Toxicol 133-164. DOI: 10.1007/978-3-7643-8340-4_6.

Theo MM, Victor PK, Willy LS, Dieudonné MEA. 2020. Evaluation du profil métallique et biologique de la pollution de l'air atmosphérique dans la ville province de Kinshasa, République Démocratique du Congo. Intl J Appl Res 6 (8): 115-123.

Vannucchi F, Traversari S, Raffaelli A, Francini A, Sebastiani L. 2020. Populus alba tolerates and efficiently removes caffeine and zinc excesses using an organ allocation strategy. Plant Growth Regul 92 (3): 597-606. DOI: 10.1007/s10725-020-00664-7.

Vázquez S, Martín A, García M, Español C, Navarro E. 2016. Metal uptake of Nerium oleander from aerial and underground organs and its use as a biomonitoring tool for airborne metallic pollution in cities. Environ Sci Pollut Res 23 (8): 7582-7594. DOI: 10.1007/s11356-0156002-5.

Venkateswarlu K, Nirola R, Kuppusamy S, Thavamani P, Naidu R, Megharaj M. 2016. Abandoned metalliferous mines: Ecological impacts and potential approaches for reclamation. Rev Environ Sci Biotechnol 15 (2): 327-354. DOI: 10.1007/s11157-016-9398-6.

Wei B, Yang L 2010. A review of heavy metal contaminations in urban soils, urban road dust and agricultural soils from China. Microchem $\mathrm{J}$ 94 (2): 99-107. DOI: 10.1016/j.microc.2009.09.014.

Yan A, Wang Y, Tan SN, Yusof MLM., Ghosh S, Chen Z. 2020. Phytoremediation: A promising approach for revegetation of heavy metal-polluted land. Front Plant Sci 11: 395. DOI: 10.3389/fpls.2020.00359.

Yang A, Wang YH, Hu J, Liu XL, Li J. 2020. Evaluation and source of heavy metal pollution in surface soil of Qinghai-Tibet plateau. Huan Jing Ke Xue Huanjing Kexue 41 (2): 886-894. DOI: 10.13227/j.hjkx.201907195.

Youssef N, Markert B, Gurbanov E, Sevnic H, Wünschmann S. 2014. Bioindication of trace metal pollution in the atmosphere of Baku city using Ligustrum japonicum, Olea europaea, and Pyracantha coccinea leaves. J Environ Engineer Landscape Manage 22 (1): 14-20. DOI: 10.3846/16486897.2013.804828. 